\title{
ESBÔÇO DUMA HISTÓRIA DAS IDÉIAS NO BRASIL NA PRIMEIRA METADE DO SÉCULO XX $\left({ }^{\star}\right)$.
}

\section{INTRODUÇÃO}

Há alguns anos, quando estudamos o desenvolvimento da filosofia no Brasil no século XIX, tivemos ocasião de dizer que o fato que mais nos impressionara ao tratarmos daquele assunto, havia sido a variada e incessante importação de idéias que fizemos no decorrer daquele século (1).

Foi a Europa a principal fornecedora daquelas idéias e, natural era que assim tivesse sido, pois, todos nós, na América, ainda vivemos, como obsærv ju o $\operatorname{Pr}$ if. Herbert Schneider, na "franja da cultura européia" (2). Todavia, já acreditávamos então - e longe de nós qualquer veleidade de efeito continentalista - que, no curioso fenômeno da nossa identificação com a inteligência dos nossos antepassados europeus, havia talvez alguma coisa mais a atender e a examinar: diante de nós surgia o modêlo europeu mas, por certo, existia também alguma coisa mais que era mister não esquecer. Era como que uma experiência nova, uma experiência resultante do encôntro tumultuoso de idéias elaboradas em meios em que a cultura fôra já profundamente trabalhada pela história, com as condições de vida de "nações" novas, há pouco saídas do estado colonial. Já nos inclinávamos então - e pouco a pouco essa idéia se vai formando e fixando no nosso espírito - a crer que, do reflexo das culturas de importação nunca resulta pròpriamente uma simples imitação do modêlo, mas uma reelaboração dos dados recebidos que produzem frutos curiosos, resultados que são de contingências histórico-sociais senão completamente, ao menos em parte, bastante diversas daquelas que lhes determinaram o

\footnotetext{
(*). - O presente trabalho é o primeiro duma série de artigos do nosso colaborador J. Cruz Costa que aparecerão mais tarde sob a forma dum dos nossos "Cadernos" ( Nota da Rediação).

(1). - Cruz Costa, O Desenvolvimento da Filosofia no Brasil no século XIX • Evolução Histórica Nacional, pág. 357.

(2). - Herbert Schneider, A History of American Philasophy, págs. vii-viii.
} 
aparecimento do outro lado do Atlântico (3). A "pureza" daquelas idéias ou doutrinas altera-se em face dos fatôres devidos às novas circunstâncias e, dêsse modo, as doutrinas ou idéias de importação não determinam, se assim podemos dizer, algo que possua sentido e valor idênticos ao que aquelas idéias ou doutrinas possuem nas suas próprias fontes.

A nossa maneira de ser não parece pois derivar apenas da importação. As idéias de importação foram, e ainda hoje são, no entanto, poderosas sugestões que ressoaram e ressoam ainda agora, com maior ou menor intensidade, nas nossas elites intelectuais e que encaminharam e ainda encaminham, em parte, os nossos países para o descobrimento de nós mesmos. Essa é uma das primeiras dificuldades - um dos primeiros contrastes - com que nos encontramos ao estudar a história das nossas idéias.

Situados em condições diferentes daquelas em que tiveram origem dos modelos que se apresentaram, desde o século XVI à nossa sensibilidade ou à nossa inteligênçia, era natural que não nos pudéssemos identificar inteiramente com êles. As condições de nossa vida era mister que adaptássemos ou conformássemos aquêles modelos e que, com êles e também com aquelas condições do meio que nos rodeia, formássemos um "molde" que evolve dentro de uma linha, talvez contraditória, mas que nos parece ser própria.

A nossa origem colonial, os rápidos progressos realizados pelo nosso continente e a angustiosa situação do momento histórico atual, nos levam a duvidar hoje daqueles modelos, que não mais parecem se coadunar com as condições dos nossos países da América, embora sejamos herdeiros e até reformadores do patrimônio cultural do qual a Europa, sem o querer, nos obrigou desde o século XVI, a participar. Poderá parecer também que as idéias que tiveram influência nos nossos países, principalmente no decorrer do século XIX, se nos afigurem já como alguma coisa muito afastada no tempo, pelo fato de pertencermos a um continente de ritmo histórico acelerado. E' por isso, talvez, que, com certa afoiteza, pretendemos, muitas vêzes, resumir - com a simplicidade de jovens que consideram os mais velhos, mais velhos do que realmente o são as influências que as idéias do século XIX exerceram sôbre nós e

(3). - O Prof. Ralph Barton Perry, da. Universidade de Harvard, num interessante trabalho publicado em Philosophy and Phenomenological Research, assim se expressava: "a filosofia, como qualquer outro ramo da investigaçäo, aspira a ser verdadeira e, conseqüentemente, universalmente válida. Nāo pode, pois, apresentar-se como nacional. Por outro lado, é impossivel escapar da influência do nacional". E acrescentava, referindo-se aos Estados Unidos: "Embora nos Estados Unidos não existia um corpo de doutrinas nem uma escola filos6fica que possa ser considerada como norte-americana, existe, no entanto, um "molde intelectual" que foi criado nos Estados Unidos como resultado de sua história, de sua origem étnica e de seu ambiente natural e que se reflete no tipo do filosofia que tendeu a predominar e a prevalecer". (Ralph B. Perry, "Is There " North American Philosophy?" in, Philosophical and Phenomenological Research, 1949, vol. ix, p. ${ }^{0} 3$, pág. 368 . 
que as releguemos ao rol dos objetos dignos de museus. Todavia, impossível nos é compreender o presente e vislumbrar as perspectivas que se podem abrir para nós, sem que voltemos a atenção para um passado que aparentemente nos pode parecer afastado mas que, de fato, ainda é bastante presente. E' preciso, porém, não esquecer quando se estuda a América, que há cento e oitenta anos, a mais poderosa república de nosso continente ainda era uma colônia.

Mas, se o século XIX é ainda tão próximo, que dizer então desta primeira metade do século $\mathbf{X X}$, durante a qual a nossa ação na vida universal se tornou mais importante e de maior responsabilidade? Assim, se difícil é estudar o que foi e o que significa efetivamente a história das idéias no decorrer do século XIX, maiores dificuldades se apresentam ainda no exame dos cinqüenta anos dêste século $\mathrm{XX}$, sobretudo para uma geração como a nossa, nascida no início dêste mesmo século e que, em virtude da data do seu nascimento, possui ainda tão estreitas ligações e compromissos com a geração da segunda metade do século passado. Não é fácil, pois, a tarefa que nos propomos. Temos receio de nos deixarmos influir, insensivelmente, no exame que tentaremos aqui delinear da história das idéias no Brasil na primeira metade dêste século - pela paixão que em nós determinaram os acontecimentos que vivemos e de dar, assim, à interpretação que iremos fazer daqueles acontecimentos, um sentido menos objetivo do que seria de desejar. Restaria, no entanto, - podemos talvez dizer - o depoimento. Se algum valor tiver, pois, êste trabalho, êsse valor será o de um depoimento.

O decênio que vai de 1868 a 1878 , escrevia Sílvio Romero, foi o mais notável período da nossa vida espiritual do século XIX (4). Até então ainda não houvera oposição à principal corrente de pensamento que o passado colonial nos legara: o catolicismo. Tão pouco haviam sofrido sérias críticas o regime monárquico, a instituição servil e os direitos tradicionais dos grandes proprietários (5). Uma verdadeira crise de renovação iria surgir porém - e de súbito - na atmosfera aparentemente tranquiila do Império. "Um bando de idéias novas", iria, a partir de 1868 , agitar o país. E' dêsse momento, cremos, que devemos datar a renovação das idéias e das condições de vida que conduzirá ao Brasil ao findar do século XIX e que lhe dará, por alguns anos ainda neste século, - talvez até

\footnotetext{
(4). - Sílvio Romero, "Explicaçōes Indispensáveis", in Tobias Barreto, Vários Es(5). - Sritos, pág. xxiii .
} 
1922 - uma determinada fisionomia que nos cabe aqui examinar para que possamos compreender a recente história da primeira metade do século $\mathrm{XX}$.

Desde o século XVIII, nós nos afastamos da tutela intelectual portuguêsa e começamos a tomar interêsse por tudo aquilo que “ia pelo mundo" (6). Não havíamos, porém, suficientemente pesado ainda, até os últimos anos do século XIX, a importância das conseqüências que as idéias dêsse mundo civilizado, para o qual se voltavam as elites brasileiras, representavam para o nossa vida e em relação às condições de nossa história. As correntes de pensamento que tiveram influência no Brasil no decorrer dêsse século foram, como é sabido, as variadas modalidades do ecletismo, o positivismo e ainda através das traduções francesas, o espencerismo e, mais tarde, as correntes da chamada "filosofia científica" alemã . O ecletismo que já se anunciara na obra de Frei Mont'Alverne quase ao findar a primeira metade do século, iria ter vigência durante todo êste século, a ponto de ser considerado por Clovis Bevilaqua, como "a filosofia que mais extensas e profundas raíses encontrou na alma brasileira" ( 7 ). Temos talvez, como sugere Gilberto Freyre, "uma capacidade especial para suportar contradições e mesmo harmonizá-las"... Isto talvez explique a extensão e a profundidade que atingiu o ecletismo em nossa terra. Em 1878, quando Sílvio Romero escreveu o seu livro, A Filasofia no Brasil, classificou as diferentes correntes de idéias no Brasil em três grupos: a dos que se haviam educado no "sensualismo francês"; a dos que representavam a "corrente néo-católica", filiada às idéias de Rosmini e de Gioberti ou a Balmes e a Ventura e a dos que seguiam Augusto Comte e Darwin (8). Mais tarde, em 1905, Sílvio Romero retomaria a sua classificação, modificando-a em parte. Dividiria então as correntes que mais atuaram no pensamento brasileiro, de modo um pouco diferente $-1 .^{\circ}$ ) aquêles que foram educados nas doutrinas dos fins do século XVIII e princípios do século XIX, dos que seguiram o sensualismo francês de Destutt de Tracy (9) e de Laromiguière e que passaram depois ao ecletismo espiritualista de Cousin e de Jouffroy; $2 .^{\circ}$ ) os puros sectários do ecletismo, como

\footnotetext{
(6). - Sílvio Romero, História da Literatura Brasileira, vol. V, pág. 151.

(7). - Clovis Bevilaqua, Esboços e Fragmentos, pág. 24.

(8). - Sílvio Romero, ob. cit., loc. cit.

(9). - Por volta de 1854, Eduardo Ferreira França publicava na Bahia, um dos grandes centros cuiturais do país, plantado pelos jesuítas, uma curiosa obra de psicologia sob o título de Investigacöes de Psychologia, na qual afirmara entio que estava "embuido das idéias da escola chanada sensualista" (Ed. F. França, Investigaçöes de Psychologia, t. I, pág. vi). Pela primeira vez (que tenhamos noticia) apareciam no Brasil, as ideias de Destutt de Tracy. $\mathbf{E}^{\prime}$ mister não perder de vista esta filiação, pois que, (isco é importante assinalar tratasdo-se de história das idéias na América), os "ideólogos" constituiram o liame entre a filosofia do século XVIII e o positivismo. (Cf. F. Picavet, Les Idéologues, cap. vii; E. Bréhier, Histoire de la Philosophie, vol. II, pág. 599 e P. Alfaric, Laromiguière et son École.
} 
Gonçalves de Magalhães e Moraes Vale; $3^{\circ}$ ) os representantes da reação católica; $4 .^{\circ}$ ) os que se orientam a princípio para o agnosticismo crítico, passando depois ao monismo haeckeliano ou às complicadas doutrinas de um filósofo pouco conhecido, Ludwig Noiré; $\left.5 .^{\circ}\right)$ aquêles que acompanharam as doutrinas de Comte e de Littré e 6. ${ }^{\circ}$ ) os sectários ortodoxos de Comte, isto é, os "ortodoxos do Apostolado". Finalmente, três outros grupos: $7 .^{\circ}$ ) $\circ$ dos evolucionistas haeckelianos; $8^{\circ}$ ) os espencerianos, e por fim, $9 .^{\circ}$ ) os representantes de "tentativas independentes" (10).

Nos primeiros anos dêste século tinham ainda vigência, algumas das correntes de idéias que, na segunda metade do século XIX, haviam exercido influência sôbre o pensamento brasileiro. E' até possível, talvez, reduzir aquelas correntes a três tendências principais: a corrente que corresponde ao pensamento tradicional, o católico, que seguirá as variantes das idéias católicas na Europa; o naturalismo ou "cientismo", impulsionado também pelas vicissitudes pelas quais passam essas doutrinas e, finalmente, a corrente que corresponde à tendência do movimento de crítica dos fins do século XIX e princípios do século XX, cujas origens são, ainda, européias. Como se vê, a cultura da Europa continua, pois, a influir na história das idéias do Brasil do início do século $\mathrm{XX}$, como já influira no decorrer da segunda metade do século anterior. Mas foi, sobretudo depois da primeira guerra mundial que o pensamento brasileiro ganhou maior independência. Apoiando-se numa realidade mais próxima, o pensamento brasileiro tenderia a transformar-se. "Vai circular cada vez mais, nos nossos livros, um perfume de mato, de terra molhada, de brisa fresca do mar. Os assuntos brasileiros, os costumes sertanejos ou praieiros, a paisagem que nos cerca, hão de dar mais espontaneidade à nossa literatura. A inspiração nacional não nos levará tão alto, mas com mais segurança, para um futuro remoto de criação e independência" (11). Começa também a preocupar os nossos homens, depois de 1914, a questão social. O surto de industrialização progressiva que se inicia com a primeira guerra e que se acentuaria cada vez mais nos anos que se lhe seguiram, traria algumas modificações na atitude da inteligência brasileira. "Da minha geração, observara Mário de Andrade, de espírito formado antes de 1914 para as gerações mais novas, vai outra diferença -: (...) nós éramos inconscientes. Nem mesmo o nacionalismo que praticávamos com um pouco mais de largueza que os regionalistas nossos antecessores, conseguira definir em nós qualquer consciência da condição do intelectual, seus deveres para com a arte e a humanidade, essas relações com a sociedade e o estado. A pressão dos novos convencionalismos políticos posteriores ao Tratado de

(10). - Sílvio Romero, A Evolução da Literatura Brasileira, págs. 93-94.

(11). - Tristão de Ataide, Contribuição à História do Modernismo, I, págs. $244-245$. 
Versalhes, mesmo no edênico Brasil se 'manifestou. Os 'nờvos quee vièram em seguida já não eram mais uns inconscientes..." (12)! O que a industrialização, decorrente das guerras, acarretou para algumas das populações urbanas do Brasil foi, sem dúvida, com uma pequena elevação do padrão de vida, um incipiente "progresso de consciência". E' certo que ao' "transoceanismo", - aquêle 'sentimento terno de saudade pela cultura e civilização européias que caracterizou muitos dos representantes da inteligência brasileira do século XIX, - sucederia um sentimento novo, mais consciente da realidade em que vivemos. Essa nova consciência deve a sua origem aos acontecimentos históricos que decorrem das conseqüências da primeira guerra mundial. Aos "espíritos europeus" como os chama José Osório de Oliveira (13) sucederiam outras gerações que, embora ainda não de todo isentas do "transoceanismo", iriam aplicar a sua inteligência a estudos concretos, relacionados com a própria terra, com o próprio meio. Assim se explica o fervor e o interêsse que despertariam os estudos sociológicos nas novas gerações formadas depois de 1914 (14). Ao transoceanismo saudosista e ao nacionalismo afoito e ingenuo de alguns literatos (15), sucederia, uma geração na qual aparecem alguns homens dotados de uma formação nova e de uma técnica intelectual mais adeqüada à compreensão dos problemas da cultura e, talvez por isso mesmo, dotados também de uma compreensão mais exata do complexo condicionalismo da vida e da história nacional (16). No entanto, apesar do sensivel progresso de consciência que se verifica em alguns dos

(12). - Mário de Andrade, Aspectos da Literatura Brasileira, pág. 239.

(13). - José Osório de Oliveira, Breve História da Literatura Brasileira, págs. 80-81.

(14). - Mário de Andrade, um dos pensadores modernos do Brasil irónicamente. diz, em um dos seus trabalhos: ". . é preciso acentuar o aspecto amatório que tomam certas ciências aqui no Brasil, principalmente a sociologia e as ciênciạs que tendem a se destacar dela, como é o caso do folk-lore. Se é certo que um Oliveira Viana, um Gilberto Freyre e poucos mais, de uma ou de outra forma, apresentam, obra honesta e valiosa, creio que algum filósofo inđiano que desejasse saber o que é a sociologia pelo que, com êsse nome se faz entre nós, se sairia mais ou menos com esta definição: a sociologia é a arte de salvar ràpidamente o Brasil" (Mário de Andrade - $O$ Empalhador de Passarinho, pág. 36)

(15). - Eduardo Frieiro tem razão quando critica o nacionalismo ingênuo de, certos literatos quando escreve: "Em vão se buscam traços da nossa psique nos caboclos, sertanejos, matutos, jagunços, gauchos e outras larvas românticas engendradas nos cérebros dos nossos escritores regionalistas de pequena envergadura..." (Eduardo Frieiro, A Ilusāo Literária, págs. 55-56).

(16). - 'E' certo que sob o ponto de vista cultural - es - revia Mário de Andrade progredimos bastante. Se em algumas escolas tradicionais ha muito atraso, junto aos núcleos de certas faculdades novas de filosofia. ciências e letras, de medicina, de economia política, já vĩo se formando gerações bem mais técnicas e bem mais humanísticas. Há um realismo novo, um ma:or interêsse pela inteligência lógica, que se observa muito bem nisso de serem agora mais numerosos os escritores que iniciam a carreira esrrevendo prosa e interessados só por ela, quebrando a tradição do livrinho de versos inaugural. Esta melhoria sensivel da inteligência técnica se manifesta principalmente nas escolas que tiveram o bom senso de buscar professôres estrangeiros, ou nosmo brasileiros educados noutras terras, os quais trouxeram de seus costumes culturais e progressso pedagógico uma mentalidade mais sadia que desistiu do brilho e da arivinhação". (Mário de Andrade, Aspectos da: Literatura Brasileira", pág. 238). 
representantes da inteligência brasileira do momento atual, a história das idéias do Brasil ainda continua a reproduzir os traços indi-. cados por Mário de Andrade na curiosa figura que é Macunaima, a personagem da "canção de gesta" da terra brasileira. "Macunai-. ma trata de enfartar-se de tôdas as comezainas, de tôdas as frutas. Fala de indumentária, mas veste-se pouco (...) canta tôdas as canções e dansa tôda música. E' o herdeiro ladino mas ignorante de tôdas as ideologias, de tôdas as culturas, de todos os instintos" (17). Macunaima - que a tantos irrita - anda, porém, por aí, herdeiro livre que é de tôdas as ideologias (18), imitando-as, deformando-as, adaptando-as, afeiçoando-as... Desafia esquemas e interpretações porque, com certeza, possui uma que se esconde n'um mundo de contrastes que é difícil de apreender e mais ainda de ca-... sacterizar...

(17). - Andrade Muricy, A Nova Literatura Brasileira, págs. 353-354.

(18). - "Na nossa época, escreve Eduardo Frieiro, o nacionalismo integral é idéia que briga com a realidade notadamente em paises do tipo do Brasil, em que tudo é trazido de fora: o homem, a língua, a religião, os costumes, as instituições, as idéias, as artes, as indústrias" (Ed. Frieiro, A Ilusão Literária, pág. 61). 


\title{
I PARTE \\ CAPITULO I
}

\author{
As origens.
}

A concepção que os homens possuiam do mundo físico, assim como do mundo moral, passaria, a partir do século XVI, por grandes transformações. Os descobrimentos marítimos revelariam ao velho mundo, um mundo novo, com povos e civilizações desconhecidas. Uma cultura nova, de base experimental e de tendência crítica (1), que até então procurara o seu caminho, desenvolver-se-ia agora com mais fôrça e com tôda plenitude. A "subitaneidade e a expansão dos grandes acontecimentos produzidos nos domínios da geografia, da história natural, da astronomia, da erudição, da técnica e das mundividências, cuja correlação simultânea constitui um dos mais sutis problemas da sociologia da ciência, não se verificam, como é óbvio, apenas em Portugal, mas apresentaram-se entre nós - escreve o Prof. Joaquim de Carvalho - com características peculiares" (2). Uma dessas características é um "pragmatismo vivido" (3), um "sentido utilitário" que nasceria das necessidades práticas dos descobrimentos e da colonização (4).

Tal era, no agitado e confuso momento histórico dos descobrimentos, o significado das idéias no pensamento português. Aliás, é preciso não esquecer, nunca foi a contemplação pura, um dos característicos do pensamento ibérico. Assim, no cenário americano, - "espaço aberto, campo propício para todo livre esfôrço, para as possibilidades, para a esperança do europeu" (5) - desenvolverse-ia uma fascinante aventura e nele se expandiria uma concepção do homem considerado como "fator do próprio destino, pela sua vontade e esfôrço, $(\ldots)$, a reivindicação da história como progresso e a viragem da mundividência teocêntrica para a polarização an-

\footnotetext{
(1). - Cf. Jaime Cortezão, Teoria Geral dos Descobrimentos Portugúêses, págs. 48-49. Cf. Cruz Costa, Ensaio sôbre a vida e a cbra de Francisco Sanchez, in Boletim XXIX da Faculdade de Filosofia, Ciências e Letras da Universidade de São Paulo, pág. 38 .

(2). - Joaquim de Carvalho, Estudos sôbre a Cultura Portuguêsa do Século XVI vol. I, págs. 10-11.

(3). - Vieira de Almeida, "A Dispersão do Pensamento Filosófico Português", in Revista da Faculdade de Letras de Lisboa, t. IX, pág. 176.

(4). - Joaquim de Carvalho, ob. cit., pág. 47

(5). - Francisco Romero, "Influencia" del Descubrimiento de America en las Ideas Generaies", in Humanidades, t. xxx, pág. 11.
} 
tropocêntrica da vida" (6). O sentido do útil, do imediato transparecerá nessa concepção de vida, contraditória mas rica de significado humano, que nos irá legar o aventureiro conquistador. Ali se refletirá também um "terrestre amor" (7) das realidades humanas. Não foi, pois, sem fundadas razões que um dos mais vivos e dos mais inteligentes representantes da inteligência brasileira contemporânea, João Ribeiro, escreveu em 1917, que o "nosso idealismo não se alonga muito longe da terra nem vai além dos mais próximos planetas..." (8).

Não é possível estudar a história das idéias no Brasil, até mesmo a que se refere ao século XX, sem atender para a importantíssima contribuição que a Companhia de Jesús trouxe para a formação nacional. A história dos jesuítas está ìntimamente ligada à história do Brasil e, muito especialmente, à história de sua inteligência (9). Já observava Capistrano de Abreu que antes de uma história dos jesuítas, "será presunçoso quem quiser escrever a do Brasil" (10).

E' mister não esquecer que a efetiva colonização do país, quem a iniciou foi $D$. João III e que foi também êste monarca que entregou, poucos anos depois da chegada de Martim Afonso de Souza a S. Vicente, o monopólio (11) do ensino universitário de Portugal aos jesuítas. A influência que os discípulos de Santo Inácio exerceram na formação da inteligência brasileira, desde a colônia até os nossos dias, é pois alguma coisa que não. se pode esquecer quando 'se estuda a história das idéias no Brasil.

A Companhia de Jesús instalou, logo ao se iniciar a colonização, - já em 1533 (12) — os seus primeiros colégios no Brasil.

\footnotetext{
(6). - Joaquim de Carvalho, ob. cit., pág. 61. Cf. Leopoldo Zea, Ensayos sobre la

(7). - Joüo de Barrcs, Histótia da Poesia Portuguêsa, págs. 40-41

(8). - João Ribeito, "A Filosofia no Brasil", in Revista do Brasil, vol. vi, pág. 255.

(9). - "A América se abria às empiêsas do espirito aventureiro dos europeus, ao mesmo tempo que Iuácio e seus companheiros se dedicavam, com voto especial, à grande obra das missōes estrangeiras. Era impossível que esta terra, revelada ao gênio europeu, $n=0$ se tomasse para os jesuítas um vasto teatro de fadigas apostólicas. A Companhia tem tôda a razão de dizer com o Padre Nóbrega: "Esta terra é nossa emprêsa; O Erasil é nosso"; mas também o Brasil pođe dizer: "o jesuíta é nosso, pela dedicaşāo e aieto com que, desde sua cheracia, êle se colocou ao iado dos brasis, na iniância de sua vida cívica, como a etuoso e devotado pedagogo". (J. M. de Madureira, S. J. in Revista do Instituto Histórico e Gcoéráfico Brasileiro, tomo especial do Congresso Internacional de História da Anérica, t. IV, págs. 238-239. Cf. J. P. Calógeras, Cs Jesuitas e o Ensino, págs. 25 e segs.

(10) . - Capistrano de Abreu, Capítulos de História Colonial, 4a. ed, pág. 278.

(11). - Jaime Ccrtezăo, cb. cit., págs. 50-52: Eraani Cidade, Liçôes sôbre a Cultura c a Literatura Portuguêesa, vol. I, págs. 113 e segs.

(12). - Scrafim Leite, S. J., História da Companhia de Jesús no Brasil, vol. I, pág. 37.
} 
As primeiras "elites" de homens letrados, pertencentes às famílias que a agricultura do açúcar enriquecia (13), freqüentavam os colégios dos jesuítas e ali formaram o seu espírito. Assim, à riqueza que representava a posse da terra, de engenhos e de escravaria, juntava-se ainda, como "sinal de classe" (14), de distinção, a posse de uma cultura humanística haurida na pedagogia dos discípulos de Santo Inácio. Estes "letrados" são os precursores de uma concepção "orçamental" (15) de cultura que, logo nos primeiros anos da história nacional, fixaria uma das linhas do nosso pensamento, a que manifesta, desde logo, a "extraordinária plasticidade do espírito brasileiro, que o faz apto a acomodar-se a tudo e a aceitar como suas as coisas vindas de outras origens" (16).

Foram êstes letrados formados pelos jesuítas, os primeiros a ligar a história das idéias no Brasil à tradição da cultura ocidental. Mas, ao lado dêles, ao lado dêstes homens que se debruçavam à janela do Atlântico à espera de navio que lhes traria idéias e livros da Europa, outros homens prosseguiam a conquista econômica que continuava a mentalidade aventurosa dos descobridores. Estes rasgaram caminhos na selva, construiram povoados e vilas, desceram rios e esboçaram os limites da terra. Estes homens, em contacto mais íntimo com a terra e com a vida aventurosa que ela propiciava, encontrariam outros motivos de interêsse que também são apreciáveis na formação do espírito e da inteligência brasileira. Joaquim Nabuco escrevia - já no findar do século XIX - que "nós, brasileiros, pertencemos à América pelo sentimento novo, flutuante do nosso espírito e à Europa, pelas suas camadas estratificadas" (17). No nosso pensamento, assim como no nosso destino histórico, existem duas vocações: uma que nos volta para o largo oceano, que nos obriga a olhar para além dos mares, para o lado de onde nos veio a cultura. E há ainda o sertão, a imensidão da terra que fíca por detrás das serranias da costa e que nos atrai ainda, como atraiu há séculos, o aventureiro. Esta contradição, esta instabilidade ainda atormenta nosso pensamento (18). E' isso que explica, como bem observou Nelson Verneck Sodré, o "contraste singular entre uma realidade cheia de motivos nítidos e uma aparência cheia de des-

\footnotetext{
(13). - "Com a cana se instaura a colonizaçāo. O litoral brasileiro se orna com uma fímbria de civilizaçäo. Nascem cidades, abrem-se caminhos, aperfeicoa-se a vida. Forma-se uma unidade política brasileira na costa, facilitada, talvez determinada, pela solidariedade econômica. Recursos maiores permitem um levantamento do nível de vida. Aparece uma aristocracia rural nas casas-grandes do: litoral pernambucano, baiano e fluminense. Floresce a arquitetura típica do açúcar, levantam-se monumentos, igrejas, conventos, fortalezas, desponta a vida inteleztual". (Afonso Arinos de Melo Franco, Terra do Brasil, págs. 139-140).

(14). - Fernando de Azevedo, A Cultura Brasileira, pág. 178.

(15). - Viana Moog, Uma Interpretação da Literatura Brasileira, pá. 35.

(16). - Nelson Werne-k Sodré, Orientação do Pensamento Brasileiro, pág. 7.

(17). - Joaquim Nabuco, $A$ Minha Formaçāo, págs. 40-41.

(18): - Cf. Alcântara Machado, Vida e Morte do Bandeirante, pág. 245. Cf. Cruz Costa, O Pensamento Brasileiro, in Bol. cit., pág. 14.
} 
concertos" (19) : Este, porém, não há de ser, como teremos ocasião de verificar, senão um dos muitos contrastes que nos apresenta a nossa história.

Jesuítas e colonos lançar-se-iam à aventura, movidos pelo mesmo espírito utilitário que caracteriza o espírito do português da éra dos descobrimentos. O Brasil não teria, assim, como plasmadores de sua história e de sua cultura, logo nos primeiros anos da colonização, um só tipo de colonizador. Dois seriam êles: o do aventureiro e o do jesuita, movidos pela mesma audácia mas divergindo na finalidade das suas emprêsas. Estes dois tipos de colonizador realizarão conjuntamente, no século XVII, os principais trabalhos de posse efetiva da nova terra: a "consolidação do domínio luso no litoral e, no interior, a parte decisiva da conquista do sertão" (20). A Companhia de Jesús entra logo a ensinar humanidades, filosofia e teologia tal como êsse ensino era feito em Portugal (21). Mas nas suas lições, os jesuítas, os beneditinos e os franciscanos limitavam-se como era natural, a "doutrinar e a propagar" (22), simplesmente as suas doutrinas. Pouquíssimos são os documentos que existem acêrca da produção filosófica dêsses primeiros representantes do pensamento da Igreja no Brasil. Alcides Bezerra, que foi um dos iniciadores das pesquisas nesse setor, diz que os "nossos filósofos da éra colonial (...) nada trouxeram de novo. Limitam-se a repetir as especulações do seu tempo, "com fim prático, imediato, religioso ou político" (23), confirmando, assim o que acima dissemos em relação ao sentido, utilitário das idéias no pensamento português e em relação a sua constância no Brasil. As idéias continuam a possuir, no Brasil como em Portugal, o caráter de instrumento prático, "militante", se assim podemos dizer. E é talvez por isso que o jesuita Antônio Vieira, a mais curiosa figura do nosso século XVII é incluida na paupérrima enumeração dos "filósofos" do tempo (24). A Vieira juntam-se ainda, no mesmo século, os nomes quase desconhecidos de Frei Manuel do Destêrro, da Ordem Seráfica da Imaculada Conceição, que teria escrito um Tratado de Filosofia Escolástica; o de Diogo Gomes Carneiro; e o de Frei Mateus da Conceição Pina, da Ordem de São Bento, ao qual Alcides Bezerra atribui a autoria de uma Teologia Dogmática (25).

\footnotetext{
; * * *

(19). - Nelson Werneck Sodré, ob. cit., loc. cit.

(20). - Afonso Arinos de Melo Franco, Desenvolvimento da Civilização Material no Brasil, pág. 51 .

(21). - Serafim Leite S. J., ob. cit., pág. 76.

(22). - Alcides Bezerra, "A Filosofia na fase colonial", in Achêgas à História da Fi-

(23) - losofia, pág. 79 . Alcides Bezerra, ob. cit., loc. cit.

(24). "- Cf. João Lúcio de Axevedo, História de Antônio Vieira, vol. I, págs. 31 e seg.

(25). - Alcides Bezerra, ob. cit., págs. 87-88.
} 
No século XVIII começamos a escapar da influência e da tutela portuguêsa e a nos interessar "pelo que ia pelo mundo", na expressiva frase de Sílvio Romero (26). Aparecem então ao mesmo tempo que as veleidades de autonomia política, as veleidades de autonomia intelectual. Em Minas Gerais, graças ao rush que o descobrimento do ouro determinara, nasceram ricas cidades nas quais "a vida se compôs em plano mais alto, e necessidades mais completas surgiram entre os mineiros, para o corpo e para o espírito" (27). Em breve, os "quadros acanhados da Metrópole não mais podiam conter o nosso gigantismo nascente, o desenvolvimento sem ordem, mas que escapava já, forçosamente, às possibilidades de ajustamento e de contrôle do pequenino reino de onde provínhamos" (28). O exemplo da Revolução Americana e as idéias filosóficas e políticas da França, do século XVIII, chegariam até nós. De outro lado, já desde os fins dêste século, o Brasil ingressara no jôgo das lutas econômicas do mundo moderno. Desde que as minas entraram em decadência, seria o algodão o produto que estaria em evidência naquele jôgo (29). Como muito justamente observa Cáio Prado, os "domínios coloniais ibéricos já serão no século XVIII, um anacronismo" (30). E' significativo o que se verifica, por exemplo, nos Autos da Inconfidência Bahiana, em relação à situação de então (31). Em fins do século XVIII, o Brasil atinge um desenvolvimento incompatível com a ineficiente tutela portuguêsa. No domínio das idéias seria a partir de agora, a França, a orientadora das suas elites. Seria ela, como diria Santa Rita Durão, que - Brasil "tomaria por madrinha" (32).

Da vinda da côrte portuguêsa para o Rio de Janeiro, tangida pelos exércitos de Napoleão, resultariam, também, nos primeiros anos do século XIX, grandes progressos para o Brasil. Pouco de-

\footnotetext{
(26). - Sílvio Romero, História da Literatura Brasileira, vol. II, pág. 151.

(27). - Afonso Arinos de Melo Franco, Terra do Brasil, pág. 25.

(28). - Afonso Arinos de Melo Franco, ob. cit., págs. 53-54.

(29). - Cf. Cáio Prado Júnior, História Econômica do Brasil, pág. 89.

(30). - Cáio Prado Júnior, ob. cit., pág. 131.

(31). - João de Deus, um dos revoltosos de 1798, ao ser interrogado, dissera julgar que, graças à revolta, "êste pôrto (a Bahia) seria franco a tôdas as naçōes estrangeiras que nele vierem negociar, trazendo fazendas e tôdas as mercadorias, para em trôco levarem açúcares, tabaco e mais gêneros da terra, sem precisão de Portugal". De igual modo se expressara outro revoltoso, Lucas Dantas, que afirmara ser a revolta o meio de "evitar o grande furto que o Príncipe faz à praça desta cidade, bern conhecido na demora do combôio que ùltimamente daqui saiu, ficando os negociantes em têrmos de pedir esmola". (Cf. Autos da Inconfidência de 1798 in Arquivo Público da Bahia - denúncia de J. J. Sant'Ana) apud Luiz Viana Filho, $A$ Sabinada, págs, 26-27. E' importante ainda destacar a atitude dos comerciantes, nos Autos da Devessa re ferentes à Inconfidência Mineira. "Domingos Vidal Barbosa informou certa vez, a Francisco Oliveira Lopes, que os comerciantes do Rio é que tinham instigado os estudantes, que estavam na França, a se entenderem com Jefferson sôbre a liberdade do Brasil" . (Cf. Autos da Devassa da Inconfidência, vol. 3, apud Afonso Arinos de Melo Franco, Terra do Brasil, pág. 57. Cf. ainda Affonso Ruy, A Primeira Revolução Social Brasileira - 1798.

(32). - Cf. Adrien Delpech, "Da Influência estrangeira em nossas letras", in Revista do Instituto Histórico e Geográfico Brasileiro (Congresso Internacional de História da América), vol. IX, pág. 205.
} 
pois da chegada da família real, promovia o Príncipe Regente, a criação de várias instituições científicas e literárias, assim como a fundação de uma imprensa régia. Em 1814 era posta à disposição do público, uma livraria que, mais tarde, seria transformada em Biblioteca Nacional. Numa sociedade colonial e atrasada, como fôra até então o Rio de Janeiro, iriam agora ouvir-se até conferências filosóficas (33). Graças aos esforços do Conde da Barca e à inclinação de D. João VI para as artes, u'a missão de artistas franceses foi contratada para dar início à Academia de Belas Artes. Com êstes artistas vieram para o Brasil também artífices especializados, próprios, como ıeferia o decreto de 12 de agôsto de 1816, ao "me.lhoramento e progressos de outras artes e ofícios mecânicos" (34).

O século XIX parecia abrir-se, assim, de maneira auspiciosa para as artes, ciências e letras no Brasil. No domínio das idéias, no entanto, a renovação não se faria tão depressa. As velhas idéias da tradição portuguêsa permaneceriam ainda atuantes por muito tempo. E' certo que alguns dos homens que tiveram responsabilidades no govêrno de $\mathrm{D}$. João VI e, mais tarde, aquêles que dirigiriam os primeiros passos do nascente Império haviam recebido, já na própria Universidade de Coimbra - para onde iam estudar os brasileiros de famílias abastadas - a influência das idéias do século XVIII que agiram na reforma da Universidade nos "Estatutos" de 1772 (35). Foi nessa Universidade "reformada pela paixão renovadora do Marquês de Pombal, tipo completo do désposta iluminado, que José Bonifácio fêz os seus estudos superiores" (36). E' a essa Universidade que deverá a sua formação, Silvestre Pinheiro Ferreira, o antigo oratoriano que tão bem percebeu qual seria o destino que aguardava a Colônia portuguêsa da América. Em Coimbra estudara ainda José da Silva Lisboa que regeu, na Bahia, a cadeira de filosofia e que foi um dos precursores das idéias de Adam Smith no Brasil.

A Independência determinaria uma grande exacerbação nacionalista. No entanto, como notou Capistrano de Abreu, a "revolução funcional" que foi a Independência, não acarretou uma modificação tal nas circunstâncias que fôsse suficiente para que o espírito se renovasse (37). Procurando compensar o rompimento

(33). - Cf. Sylvestre Pinheiro, Prelecçóes Philosophicas sobre a Theoria do Discurso e da Linguagem, a esthetica, a diceosyna e cosmologia, Rio de Janeiro, Imprensa Régia, 1813.

(34). - Cf. José Silvestre Ribeiro, Histótia dos Estabelecimentos Científicos, Literários e Artísticos de Portugal, pág. 62.

(35). - Cf. Ernani Cidade, Ensaio sôbre a Crise Mental do século XVIII, págs. 53-78.

(36). - Octávio Tarquino de Souza, José Bonifácio, pág. 24.

(37). - Capistrano de Abreu, Estudow, (1a. cérie), pág. 99. 
- político - e literário - com. Portugal, nota-se nas obras de um dos mais importantes letrados daquela época, em Domingos José Gonçalves de Magalhães, por exemplo, uma preocupação ainda de caráter pragmático: a literatura aí confina com a política, "sem que as separe uma linha muito nítida" (38). Será precisamente Domingos José Gonçalves de Magalhães, o futuro Visconde de Araguaia, o "pioneiro do nacionalismo literário (...), o arauto do romantismo brasileiro e finalmente mas not least, da orientação francesa de nossa vida espiritual, orientação que ainda prevalece nos dias atuais" (39).

Já a partir dos fins do século XVIII, como vimos, os letrados brasileiros haviam procurado furtar-se à tutela intelectual portuguêsa.

Mont'Alverne e Gonçalves de Magalhães introduzem no início do século XIX, no Brasil, as idéias da filosofia francesa da época da Restauração. No sensualismo de Condillac, e, mais tarde, no ecletismo de Victor Cousin, encontrariam os nossos patrícios motivo para dar plena expansão aos dotes oratórios e ao seu gôsto pelo palavreado e, também, para justificar a situação política da época. O ecletismo, doutrina "mais literária que filosófica, mais eloqüente que profunda, tôda ela esmaltada de citações clássicas", como diz Raymond Lenoir (40), parecia calhar perfeitamente à educação "ornamental" que recebiam os letrados e convir ao espírito da incipiente aristocracia de proprietários rurais conservadores, à "achinelada aristocracia", como a chamou o Visconde de Inhomirim. Explica-se ainda a facilidade da adoção daquele sistema: o ecletismo propunha, na época, às correntes filosóficas e políticas, uma grande reconciliação. (41). E' mister não esquecer que o primeiro império foi um período de grande agitação. Em 1828, a Aưrora Fluminense apregoava: "nada de excessos. Queremos a Constituição, não queremos a Revolução" (42). Ao mesmo tempo aquêle jornal moderado lembrava o exemplo "dos estadistas norte-americanos que estavam realizando com prudência e sabedoria a maior política do século" (43). Dêsse modo, na agitação reinante já se faziam ouvir, contraditòriamente, as influências decorrentes das

\footnotetext{
(38). - Sérgio Buarque de Holanda, "Prefáiio Literário", in Obras Completas, de D. J.

(39). - G. Márgalhães, pág. $\mathbf{x}$. de Sérgio Buarque de Holanda é datádo de 1939.

(40) . Raymond Lenoir, Condillac, pág. 155.

(41). - Cf. E. Bréhier, Histoire de la Philosophie, t. II, págs. 657-658. Cf. H. Taine, Les Philosophes Classiques du XIXe siècle, págs. 306-307.

(42). - Apud Octácio Tarquínio de Sonza, Evaristo da Veiga, pág. 88.

(43). - Octávio Tarquínio de Souza, ob. cit., pág. 93. "Sem falar abertamente na democracia, a Aurora - escreve Octácio Tarquínio de Souza - combatia os que propugnavam a necessidade de uma "cốrte pomposa", de um "aparatoso exército", de um "enxame de diplomatas". Já havia ali em" germe o regime de austeridade republicana dos tempos regenciais e bem se sentia a influência dos costumes políticos norte-americanos, com os seus presidentes meio patriarcais, com a sua ogerisa as titulos que pudessem ter de longe laivos de aristocracia" (Octávio Tarquínio de Souza, ob. cit., pág. 95)..
} 
idéias monárquico-constituicionais da filosofia da Restauração que iriam triunfar na primeira parte do Segundo Império e, ainda, as que correspondiam à "ideologia" do século XVIII. Estas continuavam sempre a animar os sentimentos republicanos e americanistas de um número não pequeno de brasileiros (44).

Não devemos sobrestimar, porém, quando se estuda a história das idéias no Brasil, a importância pròpriamente dita das teorias filosóficas. Como muito justamente observa um historiador contemporâneo, as "coisas máximas que realizamos têm sempre um sabor de empirismo, de improvização imposta pelas circunstâncias ocasionais" (45). De fato, o que mais conta no evolver da nossa história, é um certo pragmatismo que nos vem da herança portuguêsa ou do imediatismo próprio da nossa vida de povo de formação ainda recente. Precário resultado obterá - diz ainda aquêle autor - quem queira ir buscar na evolução da nossa história, as "grandes linhas de um pensamento amadurecido" (46).

Parece existir entre nós, naqueles que possuem uma visão mais clara das circunstâncias que nos rodeiam, uma certa repulsa, uma certa desconfiança pelos sistemas e pelas doutrinas, como se aquêles sistemas e doutrinas, nascidos em climas estranhos ao nosso não condizessem exatamente com as complexas circunstâncias em que vivemos. No fundo, continuamos a nos nortear, embora sempre indecisos, pela experiência vivida que desafia o doutrinarismo superficial de glosadores e comentadores do pensamento e da vida histórica alheia. Já em 1876, quando Sílvio Romero escreveu o seu livro sôbre a Filosofia no Brasil, observara que a "leitura de um escritor estrangeiro, a predileção por um livro de fora, vem decidir da opinião de um autor sôbre nós" (47). Daí o fato de ter sido a filosofia, pròpriamente dita, simples glosa e mero comentário do pensamento alheio. No domínio da filosofia, tal como a têm entendido muitos dos nossos letrados, não passamos de simples diletan-

\footnotetext{
(44). - Desde os fins do século XVIII, desde a Inconfidência Mineira, foi constante a aspiração republicana no Brasil. Em 1817 uma revolução de caráter republicano estalava em Pernambuco. No Rio de Janeiro, mais tarde, o Repúblico atacava as instituiçöes monárquicas e defendia o federalismo e as idéias republicanas. Em 1835, Bento Gonçalves proclamava a República de Piratinim que se manteria em guerra civil contra o Império durante dez anos. Em 1837, Rocha Vieira proclamava na Bahia, a sua república baiana e a própria revolução liberal de 1842, apresentava tendências republicanas. Oscar de Araújo no seu livro - L'Idée Républicaine au Brésil, escreve: "En 1842, São Paulo et Minas font une révolte dont le but republicain soigneusement dissimulé était cependant évident, si bien que $M$. Silva Jardim, se trouvant à Minas dans une excursion de propagande républicaine en 1889 , s'est entendu dire plus d'une personne, en guise de profession de foi et d'adhésion à sa campagne antimonarchique: Vous pouver compter sur moi, vous savez; j'ai été du motrvement de 1842". (Oscar de Araújo, ob. cit., págs. 32-33). Cf. Aluísio de Almeida, A Revolução Liberal de 1842, pág. 43.

(45). - José Maria Belo, História da República, pág. 12.

(46). - José Maria Belo, ob. cit., pág. 13.

(47). - Silvio Romero, A Filosofia no Brasil, págs. 35-36.
} 
tes (48). Falta-nos consciência clara de nossa própria situação. Não serão, pois, apenas os nossos "filosofantes", que são meros comentadores, os que nos ajudarão a compreender o significado das idéias no Brasil. E' no conjunto dos contrastes que encontramos no fluir da vida brasileira que devemos procurar a significação ou o sentido de nossa vida, de nossa cultura e de nossa história. Esse estranho empirismo que é, como já dissemos, um legado da cultura portuguêsa, ainda vive em nosso espírito. A constante improvização que as sempre renovadas circunstâncias nos impõem, constitui talvez a nossa maneira de ver as coisas, o nosso modo de ser.

No mundo de contrastes que somos, era compreensível, pois, que o ecletismo tivesse sido, e seja talvez ainda, a "filosofia que mais extensas e profundas raízes encontrou na alma brasileira" (49).

(Continuta no próximo número).

\section{J. CRUZ COSTA}

Professor de Filosofia da Faculdade de Filosofia, Ciências e Letras da Universidade de São Paulo.

(48). - Silvio Romero, ob. cit., pág. 168.

(49). - Clovis Bevilaqua, Eabogos e Fragmentos, pág. 24. 